\title{
KEKERASAN DALAM PENDIDIKAN; Sejarah, Perkembangan dan Solusi
}

\author{
Halimatus Sa'diyah' \\ IIAIN Madura
}

\begin{abstract}
ABSTRAK
Kajian tentang sejarah kekerasan dalam pendidikan belum banyak dibahas selama ini terutama di Indonesia, padahal hal itu sangat penting untuk dikaji dan dicarikan solusi agar tidak tidak terjadi lagi kekerasan dalam Pendidikan. Dunia pendidikan memang sering dikaitkan dengan terjadi aksi kekerasan mengingat banyaknya kasus kekerasan yang telah terjadi selama ini terutama di Indonesia. Peneliti berusaha mengkajinya untuk menemukan tipologi kekerasan dalam pendidikan dan bagaimana cara mengatasi persoalan kekerasan yang terjadi dalam pendidikan. Adapun tulisan ini termasuk jenis kajian pustaka (library research) melalui analisis konten yang diperoleh dari beberapa referensi baik berupa buku dan artikel ilmiah. Hasil dari penelitian ini adalah merumuskan konsep pendidikan perdamaian (peace education) yang dapat melatih anak didik dalam meredam konflik agar tercipta kondisi yang damai baik secara intra personal, maupun interpersonal. Pendidikan perdamaian - yang merupakan substansi pendidikan Islam - bukan hanya mengajarkan peserta didik untuk berfikir (think), akan tetapi menstimulasi peserta didik agar dapat berfikir kritis (think critically). Hal itu dapat dilaksanakan dengan menggunakan pendekatan holistik dan partisipatif melalui metode dialog agar pembelajaran lebih bermakna.

Kata Kunci: Pendidikan Perdamaian, Pendidikan Islam, Kekerasan.
\end{abstract}

\section{ABSTRACT}

Studies on the history of violence in education have not been widely discussed so far, especially in Indonesia, even though it is very important to study and find solutions so that violence does not occur again in education. The world of education is often associated with acts of violence considering the many cases of violence that have occurred so far, especially in Indonesia. Researchers try to study it to find a typology of violence in education and how to overcome the problem of violence that occurs in education. This paper is a type of library research through content analysis obtained from several references in the form of books and scientific articles. The result of this research is to formulate the concept of peace education (peace education) which can train students in reducing conflict in order to create peaceful conditions both intra-personally and interpersonally. Peace education - which is the substance of Islamic education - not only teaches students to think, but also stimulates students to think critically. This can be carried out using a holistic and participatory approach through the dialogue method so that learning is more meaningful.

Keywords: Peace Education, Islamic Education, Violence.

\section{A. Pendahuluan}

Kekerasan yang sejatinya dikenal dalam kehidupan tentunya memiliki makna yang negatif berkaitan dengan perilaku-perilaku yang tidak menyenangkan terhadap individu atau kelompok. Perilaku yang kekerasan tidak hanya dilakukan secara fisik, akan tetapi perilaku kekerasan juga banyak dilakukan melalui non fisik yang mengarah pada sisi psikologis seseorang. ${ }^{1}$ Dengan segala efek yang ditimbulkan, perilaku kekerasan patut dikhawatirkan oleh semua kalangan termasuk dalam kalangan

\footnotetext{
${ }^{1}$ Keliat, Model Praktik Keperawatan Jiwa (Jakarta: EGC, 2012), 22.
} 
pendidikan yang menjadi sorotan tersendiri dengan kasus-kasus kekerasan yang terjadi saat ini.

Dunia pendidikan memang sering dikaitkan dengan terjadi aksi kekerasan mengingat banyaknya kasus yang telah terjadi dalam dunia pendidikan. Seperti yang dilansir oleh Media Indonesia.com bahwa beberapa kasus kekerasan yang terjadi di dunia pendidikan dan mencuat dalam beberapa bulan terakhir di Indonesia ini mengindikasikan adanya tindak kekerasan yang melibatkan hampir semua stakeholders sekolah, yaitu guru, pegawai, siswa, dan bahkan orang tua. Hal itu dibuktikan dengan adanya kasus tewasnya siswa di SMA Taruna Nusantara, dan tak terhitung kasus yang menjerat siswa, guru, dan orangtua dalam perilaku kekerasan, serta perlakuan kasar kakak kelas terhadap adik kelas saat proses penerimaan siswa baru. ${ }^{2}$ Kekerasan yang terjadi tidak hanya kekerasan fisik saja, akan tetapi kekerasan psikis bahkan kekerasan seksual, sebagaimana yang ada dicatatan kementerian Pendidikan Nasional di tahun 2014 terdapat lebih dari 230 berita kekerasan anak/pelajar di media daring selama periode bulan Oktober-November 2014. ${ }^{3}$ Hal itu menunjukkan bahwa kekerasan dalam dunia Pendidikan memang menjadi persoalan tersendiri dan perlu dicarikan solusinya.

Banyaknya kasus kekerasan dalam Pendidikan mulai tingkat Sekolah Dasar (SD) sampai Perguruan Tinggi (PT). Sebagaimana penelitian yang dilakukan oleh LSM Plan International dan International Center for Research on Woman (ICRW) pada tahun 2015 yang menunjukkan bahwa terdapat $84 \%$ anak Indonesia pernah mengalami kekerasan di sekolah. ${ }^{4} \mathrm{Hal}$ itu tentunya disebabkan oleh beberapa faktor, yaitu faktor internal dan faktor eksternal. Secara naluriah, setiap manusia memiliki sikap keberanian dan sikap memberontak. Akan tetapi, ketika lingkungan sekitar mengajarkan bagaimana bisa mengendalikan hawa nafsu dan mengontrol sikap emosi ketika berinteraksi dengan orang lain, akan menjadikan manusia lebih bersikap tenang, dan bijak dalam menyikapi persoalan. Sehingga tidak akan ada kekerasan, melainkan kehidup damai dan tenteram.

Sejatinya perilaku kekerasan dalam dunia pendidikan sangat tidak diinginkan terjadi mengingat dampaknya yang sangat berbahaya terhadap anak. Selain mengakibatkan cacat jasmani yang disebabkan oleh kekerasan fisik, juga

\footnotetext{
2 Media Indonesia, “Kekerasan dalam Pendidikan”, dalam https://mediaindonesia.com/read/detail/100955kekerasan-dalam-pendidikan, diakses pada 30 Desember 2020.

${ }^{3}$ Anies R. Baswedan, 'Gawat Darurat Pendidikan di Indonesia', in The Emergency of Indonesian Education]. A Paper Delivered at the Meeting between Ministry and Head of Education Offices Indonesia-Wide in Jakarta, on December, vol. 1, (2014): 27.

4 Kata Data, "Anak Indonesia Alami Kekerasan di Sekolah, dalam https://databoks.katadata.co.id/datapublish/2017/02/10/84-anak-indonesia-alami-kekerasan-di-sekolah. Diakses pada 22 Januari 2021.
} 
mengakibatkan trauma yang disebabkan oleh kekerasan psikologis. Selain itu, dampak negatif lain dari adanya perilaku kekerasan yaitu terbentuknya karakter anak di masa mendatang yang dipengaruhi oleh peristiwa-peristiwa yang pernah dialaminya (kekerasan), bahkan dapat menimbulkan gangguan mental saat dewasa. ${ }^{5}$ Oleh karena itu keberlanjutan kajian tentang kekerasan dalam pendidikan sangat perlukan untuk mengetahui hal-hal yang melatarbelakangi adanya kekerasan dan solusi yang ditawarkan di dalamnya.

Untuk mengetahui beberapa tipologi kekerasan dan pemicu terjadinya kekerasan dalam pendidikan, ada baiknya mengkaji sejarah terjadinya kekerasan dalam Pendidikan di Indonesia. Penulis mencoba melacak kasus kekerasan yang terjadi dari masa ke masa. Kemudian dilakukan analisis content untuk mengidentifikasi pemicu adanya kekerasan dan memberikan solusi atas persoalan kekerasan yang terjadi di sekolah.

\section{B. Kekerasan dalam Pendidikan dari Masa ke Masa}

Kekerasan dalam bahasa Inggris biasa disebut dengan "violence" yang sangat erat dengan bahasa latin "vis" (daya kekuatan) dan "latus" (yang berasal dari dari kata "ferre" (membawa) yang diartikan membewa kekuatan. Dalam kamus bahasa Indonesia diartikan sifat atau hal yang keras, kekuatan dan paksaan. Sedangkan dalam kamus New Oxford Dictionary, kekerasan didefinisikan sebagai "behavior involving physical force intended to hurt, damage, or kill someone or something". ${ }^{6}$

Kekerasan di Indonesia dapat dilacak sejak masa pra-kolonial. Banyak sekali tulisan dan tayamgam tentang kekerasan yang dilakukan pada masa Orde Baru, kekerasan pada gerakan 30 September 1965-1966 sampai pada kekerasan pada masa penjajahan Belanda. ${ }^{7}$ Catatan sejarah kekerasan pada masa pra-kolonial memberikan penjelasan bahwa ada beberapa faktor penyebab adanya kekerasan. Pires berpendapat bahwa masyarakat Indonesia secara inheren memiliki potensi untuk melakukan kekerasan. Sebaliknya rafless berpendapat bahwa kekerasan yang dilakukan oleh masyarakat karena disebabkan oleh faktor tekanan dari pemerintahan kolonial Belanda. $^{8}$

\footnotetext{
${ }^{5}$ Alit Kurniasari, “Dampak Kekerasan Pada Kepribadian Anak”, Sosio Informa, Vol.5, No.1 (Januari, 2019): 1-10

${ }^{6}$ Newton Garver, "What violence is"? dalam Philosophy a New Generation (New York: A.K. Bierman dan J Gould, 1970), 349-370.

7 Arinto Nur Cahyono, “Kekerasan sebagai fenomena Budaya: Suatu Pelacakan terhadap Akar Kekerasan di Indonesia", Mimbar, Vol. XIX, No.3 (Juli -September 2003): 243-260.

8 Ibid., 259.
} 
Pada awal abad ke-16 ketika Portugis datang ke Indonesia kemudian disusul oleh bangsa Spanyol yang membawa missionaris menyebarkan agama Katolik kepada penduduk Indonesia. Mereka mendirikan sekolah-sekolah sebagai tempat belajar anakanak. Salah satunya adalah sekolah Seminarie di Ternate yang didirikan untuk anak orang kalangan atas. Selain pelajaran agama di sekolah itu juga ada pelajaran menulis, membaca dan berhitung. Tidak hanya di Ternate ada juga sekolah seminarie di Solor yang muridnya kurang lebih 50 orang dengan menggunakan Bahasa Latin. Pada tahun 1546 sudah ada 7 kampung yang penduduknya beragama Katolik dan disana juga ada pengajaran untuk masyarakat umum, bukan hanya untuk kalangan elit. Pada akhir abad ke-16 terjadilah pemberontakan, sehingga habislah kekuasaan Portugis di Indonesia. Sehingga riwayat misi Katolik juga hilang di Maluku. Tidak banyak informasi yang didapat pada masa ini tentang kekerasan dalam Pendidikan, karena memang hanya orang-orang tertentu saja yang mendapatkan kesempatan untuk sekolah dan Portugis hanya menguasai beberapa wilayah saja di Indonesia. ${ }^{9}$

Berakhirnya kekuasaan Portugis di Indonesia menyebabkan Belanda tertarik untuk menjajah Indonesia, awalnya Belanda bertujuan untuk berdagang di Indonesia. Tidak hanya itu saja, belanda juga mengganti misi portugis yang beragama Katolik menjadi agama Protestan, sehingga mereka mendirikan sekolah-sekolah di daerah yang dahulu dinasranikan oleh Portugis dan Spanyol. Pada tahun 1607 Belanda mendirikan sekolah pertama di Ambon. Adapun pelajaran yang diberikan antara lain adalah membaca, menulis, dan sembahyang. Gurunya diangkat oleh Belanda dan diberi gaji. Selain itu Belanda mendirikan sekolah di Jakarta pada tahun 1617 yang terdiri dari 92 murid laki-laki dan 45 murid perempuan menggunakan Bahasa Belanda sebagai Bahasa pengantar. Tujuannya adalah menghasilkan tenaga kerja yang cakap, yang kelak akan dimanfaatkan oleh Belanda dalam pemerintahan, administrasi dan di gereja. Meskipun begitu, di abad ke-17 dan 18 belum ada sekolah kejuruan, fokusnya hanya pada sekolah keagamaan saja. Sekolah kejuruan baru muncul di abad ke-19. ${ }^{10}$

Baru apada abad ke-20 muncul golongan-golongan baru dari kaum cendekiawan yang telah mendapatkan Pendidikan di Barat, namun tidak mendapatkan perlakuan yang wajar dari masyarakat colonial. Sehingga Pendidikan yang telah diperoleh ketika di Barat menimbulkan kesadaran nasional dan keinsyafan bernegara. Timbullah

\footnotetext{
${ }^{9}$ Sjamsuddin, Sejarah Pendidikan Di Indonesia Zaman Kemerdekaan (Jakarta: Direktorat Jenderal Kebudayaan, 1993), 13.

10 Sjamsuddin, Sejarah Pendidikan Di Indonesia Zaman Kemerdekaan (Jakarta: Direktorat Jenderal Kebudayaan, 1993), 13.
} 
pergerakan yang dicetuskan oleh kaum cerdik pandai yang sebagian besar adalah keturunan bangsawan. Pada tahun 1908 muncul partai Sarekat Islam. Ada organisasi Muhammadiyah, Indische Patij yang diambil alih PNI danpada tahu 1928 diterjemahkan menjadi “Indonesia Merdeka". 11

Masa penjajahan jepang hanya berlangsung dari 7 Maret 1942 sampai 17 Agustus 1945. Semenjak Indonesia dikuasai oleh Jepang, segala usahanya orientasinya adalah untuk perang. Siswa yang sekolah disuruh bergotong royong mengumpulkan batu kerikil dan pasir untuk membuat benteng pertahanan. Bahkan siswa disuruh menanam sayursayuran dan bahan makanan untuk bahan makanan buat kepentingan perang. Bisa dikatakan pada masa penjajahan perang ini puncaknya kekerasan dalam Pendidikan, siswa di jadikan pekerja oleh Jepang. Pemerintahan Jepang berhasil melenyapkan sekolah-sekolah untuk anak Belanda dan juga sekolah untuk kalangan atas. Sedangkan sekolah rendah yang ada di desa masih tetap bertahan. Seperti Sekolah Rakyat (SR) selama 6 tahun, sekolah menengah selama 3 tahun, dan juga sekolah kejuruan. Jepang menganggap sekolah sangat penting karena akan menyiapkan tenaga dalam jumlah yang banyak untuk proganda jepang kepada siswa. ${ }^{12}$

Sejak terpilihnya Ir. Soekarno sebagai presiden pertama Republik Indonesia, ia membawa semangat kebangsaan nasionalisme dan pembentukan karakter dalam Pendidikan. Pendidikan yang awalnya ketika masa kolonial sangat intelektualis dirubah menjadi Pendidikan yang membentuk kepribadian yang dapat mengembangkan kepercayaan diri, keberanian, inisiatif dan semangat bekerja. ${ }^{13}$. Dilanjutkan beberapa bulan kemudian Menteri Pendidikan Pertama Ki Hajar Dewantara mengeluarkan instruksi yang berisi tentang seruan agar membuang sistem pendidikan kolonial dan mengutamakan patriotisme. ${ }^{14}$ Secara serentak para guru mengganti sistem pengajaran kolonial dengan pengajaran untuk membangun semangat kebangsaan. ${ }^{15}$ Akan tetapi pada praktik Pendidikan di sekolah, masih ada sisa-sisa Pendidikan kolonial yang diterapkan oleh guru kepada siswanya, yaitu dengan memberi sanksi keras kepada siswa ketika melanggar peraturan sekolah. Seperti keliling lapangan, dibentak bahkan dipukul. Ketika ada upacara baris berbaris di lapangan, banyak siswa yang pingsan karena latihan fisik yang berat, dan tidak manusiawi. Lain lagi persoalan kekerasan

11 Ibid., 15.

12 Ibid., 20.

13 Zuhdi Susanto, Identitas Bangsa, Sejarah Pendidikan Di Indonesia (Denpasar: Pustaka Larasan, 2010), 217.

14 H.A.R. Tilaar, Kekuasaan Dan Pendidikan Pengantar Pedagogik Transformatif Untuk Indonesia (Magelang: Indonesia Tera, 2012), 148.

15 Sjamsuddin, Sejarah Pendidikan Di Indonesia Zaman Kemerdekaan (Jakarta: Direktorat Jenderal Kebudayaan, 1993), 13. 
terhadap disabilitas yang juga kerap terjadi di dunia Pendidikan, mulai dari di ejek, dihina bahkan sampai bullying di sekolah, ${ }^{16}$ menyebabkan penyandang disabilitas kurang bisa mengeksplorasi kemampuan yang dimilikinya. Nampaknya sampai saat ini juga penyandang disabilitas masih tetap dijadikan sebagai objek kekerasan. ${ }^{17}$

Pada pemerintahan Orde baru, Soeharto melancarkan usaha pembangunan terencana mulai Pelita I sampai pada Pelita III dan seterusnya. Pemerintahan orde baru membawa jargon pembangunan di sector ekonomi. Pada saat itu Pendidikan diarahkan untuk membekali generasi muda agar mampu membawa bangsa dan negara agar sejajar dengan negara maju. ${ }^{18}$ Sistem Pendidikan mengatur Pendidikan yang erat hubungannya dengan kehidupan politik bangsa saat itu. ${ }^{19}$ Pada periode ini Pendidikan menjadi instrument pelaksanaan program pembangunan di berbagai bidang, khususnya pedagogi, kurikulum, organisasi, dan evaluasi Pendidikan diarahkan pada akselerasi pelaksanaan pembangunan.

Sejak tahun 1983 ada penataran P4 yang wajib diberikan kepada siswa baru disemua sekolah di Indonesia. Pemerintah orde baru menegaskan bahwa P4 merupakan petunjuk operasional untuk mengamalkan Pancasila dalam kehidupan bermasyarakat. Tujuannya adalah agar terwujud sikap dan prilaku yang sesuai dengan Pancasila dan UUD 1945. Sehingga proses indoktrinasi benar-benar terjadi dalam penerapan P4 mulai dari Sekolah Dasar sampai Perguruan Tinggi.

Sistem Pendidikan pada masa orde baru lebih banyak dibangun atas kebijakan yang mereproduksi ideologi penguasa. Tidak heran jika eksitensi sekolah sebagai pemasok utama masyarakat berpendidikan hanya dijadikan sebagai media reproduktif ideologi pemerintah. Sistem Pendidikan yang dibangun sangat sentralistik, ${ }^{20}$ sehingga semua kebijakan seragam, mulai dari tingkat pusat sampai daerah semuanya sama. Bahkan gaya belajar siswa di sekolah juga tidak jauh berbeda, hanya mengikuti instruksi guru sebagai pemegang kendali proses pembelajaran di kelas. Anehnya lagi siswa tidak ada yang berani protes ketika gurunya yang menyuruh, bahkan siswa akan senang ketika guru memberikan tugas atau dihukum ketika salah, karena akan

\footnotetext{
${ }^{16}$ Bullying melibatkan interaksi dinamis antara pelaku dan korban. Kekuatan penindas meningkat, dan korban kehilangan kekuasaan. Akibatnya korban sulit merespon atau mengatasi masalah tersebut Ketidakseimbangan kekuasaan dapat berasal dari kekuatan fisik, status sosial dalam kelompok, atau dari ukuran kelompok (misalnya kelompok yang menargetkan satu orang). Liha, Syaiful Fuad, Sumarwati Sumarwati, Asma Naily Fauziyah, Zaini Tamin AR, "Strategi Guru Pendidikan Agama Islam dalam Menanggulangi Tindakan Bullying Siswa”, EL-BANAT: Jurnal Pemikiran dan Pendidikan Islam, Vol.11 No.1 (2021).

17 Baswedan, 'Gawat Darurat Pendidikan Di Indonesia'.

${ }^{18}$ Mastuhu, Pendidikan Indonesia dari Jaman ke Jaman (Jakarta: Balai Pustaka, 2003), 33.

19 H.A.R, Kekuasaan Dan Pendidikan Pengantar Pedagogik Transformatif Untuk Indonesia, 4.

20 Susanto, Identitas Bangsa, Sejarah Pendidikan Di Indonesia.
} 
mendapatkan pelajaran dari kesalahan yang diperbuatnya. Sebagai contoh, ketika guru menyuruh muridnya membersihkan kelas dan kamar mandi sebagai sanksi karena tidak mengerjakan PR, maka siswa akan menerima dengan senang hati karena memang merasa bersalah telah lalai melakukan tugasnya di rumah. Begitu juga guru memberikan sanksi kepada siswa karena memang berniat untuk melatih siswa agar disiplin dan belajar bertanggung jawab.

Belajar dari sebelumnya, maka di era reformasi ini Pendidikan dilaksanakan secara alamiah, tanpa adanya indoktrinasi yang sempat melumpuhkan Pancasila karena ambisi dari penguasa yang telah menjadi belessing in disguise. Ambisi kekuasaan di masa lalu telah berhasil mengubah hakikat Pancasila bahkan melahirkan kekuatan penghancuran diri. Sehingga di era Reformasi disusunlah rencana pembangunan jangka Panjang Nasioanal (RPJPN) tahun 2005-2025. ${ }^{21}$

Pendidikan pada era Reformasi sudah mulai terbuka, dengan adanya desentralisasi Pendidikan, membuka ruang bagi Pendidikan untuk lebih mengembangkan berbagai aspek yang dimiliki oleh peserta didik, tidak ada lagi paksaan sebagaimana ketika masa orde baru. Perubahan kurikulum dari Kurikulum 1994 menjadi kurikulum 2000 dan disempurnakan menjadi kurikulum 2002 (KBK) merupakan usaha pemerintah agar Pendidikan lebih berorientasi pada kompetensi kognitif, afektif dan psikomotorik. ${ }^{22}$

Dalam konteks kekerasan dalam Pendidikan, pada era reformasi sudah mulai berkurang karena kebebasan berpendapat sudah mulai dibuka, pola Pendidikan juga desentralistik, pemerintah daerah sudah bisa ikut andil dalam menentukan kebijakan Pendidikan. ${ }^{23}$ Begitu juga Guru sebagai pendidik sudah mulai eklusif dalam proses pembelajaran. Metode pembelajaran sudah menggunakan metode diskusi, dan sudah mulai meninggalkan metode ceramah dan hafalan. Pendidik juga sudah tidak lagi menggunakan kekerasan dalam mendidik siswanya. Penerapan disiplin tetap dilakukan, akan tetapi ketika ada pelanggaran, sanksinya tidak lagi keranah fisik, tapi lebih kepada sanksi edukatif.

Lain lagi dengan era industri seperti saat ini, dimana motivasi guru memukul siswa bukan hanya karena ingin merubah sikapnya yang tidak baik, akan tetapi lebih kepada melampiaskan hawa nafsunya. Salah satunya adalah kasus pemukulan seorang

\footnotetext{
21 Sjamsuddin, Sejarah Pendidikan Di Indonesia Zaman Kemerdekaan (Jakarta: Direktorat Jenderal Kebudayaan, 1993), 113.

22 Ibid., 115.

23 UU No. 20 Tahun 2003 tentang Sistem Pendidikan Nasional disahkan pada 8 Juli 2003.
} 
guru kepada siswanya di Purwokerto jawa Tengah yang viral di media. ${ }^{24}$ Peristiwa tersebut jelas bukan yang pertama kalinya, sehingga salah satu dari orang tua siswa melaporkan tindakan gurunya kepada pihak kepolisian. Ada juga kasus seorang guru di Sidoarjo yang harus melalui proses hukum disebabkan mencubit siswanya sampai luka. Lain lagi dengan kasus kekerasan yang terjadi di Sampang sampai menyebabkan Ahmad Budi Cahyono seorang guru seni rupa tewas karena perbuatan siswanya sendiri. ${ }^{25}$

Kasus-kasus kekerasan yang terjadi menjelaskan bahwa potensi kekerasan dapat dilakukan oleh guru, siswa atau bahkan orang tua kepada anaknya. Siapapun bisa menjadi pelaku kekerasan atau korban kekerasan. Padahal sudah cukup jelas bahwa dalam dunia Pendidikan dilarang menggunakan kekerasan, apapun alasannya, baik guru maupun siswa tidak dibenarkan menggunakan kekerasan dalam pendidikan.

Menjadikan Lembaga Pendidikan yang steril dari tindakan kekerasan merupakan hal sangat krusial, karena proses Pendidikan merupakan upaya pengembangan kemapuan intelektual, emosional dan spiritual manusia. Salah satu tujuan Pendidikan adalah memanusiakan manusia, menjadikan siswa sebagai individu yang mempunyai kehalusan budi pekerti serta kehalusan hati. Sehingga sadar bahwa kekerasan bukanlah sikap yang efektif untuk mencapai tujuan. Penggunaan kekerasan justru akan kontra produktif karena menihilkan tujuan Pendidikan. Sehingga ketika ada kekerasan di dunia Pendidikan akan menodai dan menjadi goresan yang amat mendalam.

\section{Pemicu Kekerasan dalam Pendidikan}

Fenomena kekerasan dalam dunia pendidikan dapat dilakukan oleh siapa saja, misalnya teman sejawat, kakak kelas kepada adik kelasnya, seorang guru terhadap muridnya dan bahkan juga bisa dilakukan oleh kepala sekolah terhadap staf-stafnya. Jika kita melihat kejadian ini dalam perspektif hukum, tentu tindakan semacam ini sama sekali tidak dapat dibenarkan dengan alasan dan motif apapun. ${ }^{26}$ Oleh sebab itu, hal ini tentu harus menjadi perhatian semua pihak terlebih pemerintah sebagai pemegang otoritas dan pemangku kebijakan agar tindakan kekerasan dalam dunia pendidikan tidak terus menjadi dilema kita bersama.

\footnotetext{
${ }^{24}$ Media Indonesia, dalam Baswedan, 'Gawat Darurat Pendidikan Di Indonesia'.

25 Martahan Sohuturon, 'Kronologi Siswa Aniaya Guru Hingga Tewas Di Sampang', nasional, https: / / www.cnnindonesia.com/nasional/20180202124909-12-273381/kronologi-siswa-aniaya-guru-hinggatewas-di-sampang. Accessed 31 December 2019.

${ }^{26}$ Arif Gosita, Masalah Perlindungan Anak ( Depok: FHUI, 2004), 78.
} 
Melihat dampak dari adanya kekerasan yang terjadi pada siswa di sekolah, pastinya akan mempengaruhi kemampuan mereka dalam beradaptasi, juga keterampilan mereka dalam mengatur emosional dalam dirinya. Adanya gangguan pada beberapa aspek tersebut akan menyebabkan ketidaksesuaian tahapan perkembangannya dan menimbulkan masalah kognitif, emosional, perilaku dan social. ${ }^{27}$ Anak-anak dan remaja yang menyaksikan kekerasan, misalnya di sekolah, sering juga langsung menjadi korban kekerasan dalam sekolah, maka akan memiliki kesehatan mental yang lebih buruk, berjuang dengan hubungan sosial, memiliki masalah keterikatan dan berpotensi mengembangkan Post Traumatic Stress Disorder (PTSD).

Undang-Undang tentang perlindungan anak sebenarnya telah dinyatakan dalam UU RI No. 23 tahun 2002 yang menjelaskan bahwa seorang anak memiliki hak-hak yang konstitusi harus dijaga dan dirawat serta konstitusi menjamin kesehatan yang optimal, memperoleh pendidikan, mendapatkan perlindungan. Sedangkan prinsip dasar dalam memenuhi hak-hak anak yang dijamin oleh konstitusi adalah: ${ }^{28}$ Pertama, Non diskriminasi, perlindungan anak dilakukan sesuai dengan prinsip- prinsip pokok yang terdapat dalam Konvensi Hak Anak. Kedua, kepentingan yang terbaik bagi anak (The Best Interest of The Child), bahwa dalam semua tindakan yang menyangkut anak dilakukan oleh pemerintah, masyarakat, badan legislatif dan yudikatif, maka kepentingan anak harus menjadi pertimbangan yang utama. Ketiga, hak untuk hidup, kelangsungan hidup dan perkembangan, maksudnya adalah negara harus mengakui bahwa anak adalah memiliki hak yang melekat atas kehidupan dan menjamin sampai batas maksimal kelangsungan dan perkembangan anak. Keempat, penghargaan terhadap pendapat anak, maksudnya adalah dalam setiap pengambilan keputusan negara harus menghargai dan memperhatukan setiap pandangan dan pendapat anak terutama yang mempengaruhi kehidupan anak. Dalam hal perlindungan terhadap anak setiap orang tua atau keluarga, masyarakat, dan negaralah yang harus melindungi hakhak anak tersebut.

Assegaf mendefinisikan kekerasan dalam pendidikan sebagai sikap agresif pelaku yang melebihi kapasitas kewenangannya dan menimbulkan pelanggaran hak bagi korban. Dalam hal ini kekerasan dibedakan dengan kriminalitas, karena hukum kriminalitas telah diatur tersendiri sebagaimana hukum yang berlaku di Indonesia. Kekerasan dalam pendidikan diasumsikan terjadi sebagai akibat kondisi tertentu yang

\footnotetext{
27 Science Direct, “Emotional Discomfort among School Staff and Student Teachers When They Had to "tell” or "Not Tell” about Vague Suspicions of Domestic Violence - ScienceDirect', accessed 31 December 2020.

28 Darwan Prinst, Hukum Anak Indonesia (Bandung: PT. Citra Aditya Bakti, 2003), 144-146.
} 
melatarbelakanginya, baik dari faktor internal dan eksternal, dan tidak timbul secara begitu saja, melainkan dipicu oleh suatu kejadian. ${ }^{29}$

Jika mengacu kepada definisi di atas, maka makna kekerasan cenderung mengacu kepada sifat keras, baik kekerasan secara fisik dan psikis dengan adanya pemaksaan kehendak yang dilakukan oleh setiap orang yang berada pada institusi pendidikan. Sedangkan jika melihat faktor yang melatarbelakangi tindak kekerasan dalam pendidikan juga tidak akan terlepas dengan faktor internal dan eksternal sehingga dapat dikatakan bahwa tindak kekerasan dalam sekolah tidak semerta-merta muncul begitu saja, namun ada konteks lain yang turut mempengaruhinya.

Jika kita melihat kekerasan dalam perspektif hukum, maka jelas hal itu tidak dibenarkan. Undang-Undang RI No. 20 tahun 2003 pasal 3 tentang Sistem Pendidikan Nasional memberikan amanah bahwa fungsi pendidikan nasional sejatinya untuk membentuk watak serta peradaban bangsa yang bermartabat dalam rangka mencerdaskan kehidupan bangsa, bertujuan untuk berkembangnya potensi peserta didik agar menjadi manusia yang beriman dan bertakwa kepada Tuhan Yang Maha Esa, berakhlak mulia, sehat, berilmu, cakap, kreatif, mandiri, dan menjadi warga negara yang demokratis serta bertanggung jawab". ${ }^{30}$ Lebih spesifik lagi, dalam pasal 4 ayat 1 menyatakan bahwa pendidikan harus diselenggarakan secara demokratis dan atas daras berkeadilan, dengan demikian pendidikan dijalankan dengan tidak diskriminatif serta harus menjunjung tinggi hak asasi manusia, nilai keagamaan, nilai kultural dan kemajemukan bangsa. ${ }^{31}$

Undang-Undang tentang Sistem Pendidikan Nasional sebagaimana yang dijelaskan di atas merupakan asas dan dasar yang harus dipahami oleh setiap pendidik, kepala sekolah dan semua perangkat-perangkat institusi pendidikan. Undang-Undang telah memberikan amanat bahwa pendidikan yang hendak diselenggarakan harus mengacu kepada pendidikan yang beradab dan bermartabat. Pendidikan yang diselenggarakan harus bertujuan untuk mencerdaskan kehidupan bangsa dengan cara mengembangkan potensi anak didik agar menjadi manusia yang berilmu dan berakhlaqul karimah. Untuk merealisasikan semua itu tentu harus dilaksanakan dengan cara-cara yang bermartabat pula dengan tanpa menggunakan kekerasan dalam mendidik anak dan dilakukan pada setiap jenjang dan institusi pendidikan manapun.

\footnotetext{
${ }^{29}$ Abd. Rahman Assegaf, Pendidikan Tanpa Kekerasan: Tipologi Kondisi, Kasus dan Konsep (Yogyakarta: Tiara Wacana, 2004), 37.

${ }^{30}$ Marno, Manajemen dan Kepemimpinan Pendidikan Islam (Malang: Refika Aditama, 2008), 24.

31 Ibid., 24.
} 
Melihat latar belakang terjadinya tindak kekerasan dalam dunia pendidikan sebagaimana yang dikemukakan oleh Assegaf ${ }^{32}$, memang terdapat banyak hal yang mempengaruhi semua tindakan tersebut. Dalam hemat penulis, setidaknya terdapat tiga faktor yang turut mempengaruhi dan menyebabkan terjadinya kekerasan yaitu;

Pertama, buruknya sistem pendidikan yang berlaku akan memperuhi kualitas pendidikan, tentu juga pendidikan yang tidak berkualitas juga akan sangat berpotensi terjadinya sesuatu-sesuatu yang tidak diharapkan terjadi, termasuk di dalamnya adalah tindak kekerasan. Pendidikan yang hanya berorientasi kepada pembentukan aspek kognitif dengan mengabaikan aspek yang lain cenderung akan menafikan aspek humanisasi dalam pendidikan. Oleh sebab itu, perbaikan sistem pendidikan menjadi barang tentu yang diharapkan kita bersama jika kita menginginkan praktek-praktek kekerasan dalam dunia pendidikan dapat teratasi. Kedua, faktor lingkungan masyarakat dan tayangan-tanyangan yang tidak mendidik turut memperparah keadaan. Faktanya, saat ini tanyangan-tanyangan televisi dan media sosial lainnya banyak mempertontonkan tayangan seperti perkelahian, pemberontakan, dan kekerasankekerasan yang lain. Tayangan-tayangan semacam ini harusnya menjadi tugas oleh pemerintah untuk lebih memperketat lembaga-lembaga film di Indonesia. Ketiga, kondisi sosial ekonomi pelaku kekerasan juga ikut mempengaruhi. Secara psikologis, sesorang yang berada dalam kondisi yang secara sosial dan ekonomi tidak baik tetntu ia cenderung akan lebih berpotensi melakukan tindakan kekerasan jika dibandingkan dengan orang yang secara sosial dan ekonominya baik.

Kekerasan yang ada di sekolah biasanya berupa kekerasan fisik dan psikis. Namun, yang cenderung terlihat dan menjadi perhatian adalah kekarasan fisik. Kekerasan yang terjadi biasanya apabila terdapat pelanggaran yang dilakukan oleh pihak yang menuntut adanya sanksi atau hukuman. Pada umumnya, jika sanksi yang diberikan tidak sesuai dengan kadar atau kondisi pelanggaran, maka kondisi inilah yang biasanya sangat berpotensi adanya tindakan kekerasan.

\section{Peace Education; Perdamaian dalam Konteks Pendidikan Islam}

Pada dasarnya, pendidikan berfungsi memberikan bantuan kepada peserta didik dalam mengembangkan dirinya dan karateristik kepribadiannya menuju ke arah yang lebih baik yang berdampak bagi dirinya serta di lingkungan sekitarnya, sebagaimana

\footnotetext{
32 Abd. Rahman Assegaf, Pendidikan Tanpa Kekerasan: Tipologi Kondisi, Kasus dan Konsep (Yogyakarta: Tiara Wacana, 2004), 37.
} 
Azyumardi Azra,memberikan pengertian bahwa "pendidikan" adalah merupakan suatu proses di mana suatu bangsa mempersiapkan generasi mudanya untuk menjalankan kehidupan dan untuk memenuhi tujuan hidup secara efektif dan efisien. ${ }^{33}$ Dengan adanya proses pendidikan yang baik, tentu akan terbentuk pribadi yang baik pula sesuai dengan tujuan akhir dari pendidikan yaitu memanusiakan manusia.

Kekerasan dalam pendidikan sebenarnya merupakan peristiwa akhir dari segala sikap yang tidak sesuai dengan nilai etik yang ditampilkan oleh pelaku pendidikan. Sehingga dengan adanya sikap tersebut secara tidak langsung berpengaruh terhadap pengambilan keputusan yang berujung pada tindak kekerasan. Perilaku semacam ini harus menjadi perhatian tersendiri dengan terus mencari solusi atas semua permasalahan tersebut.

Alifuddin, menjelaskan bahwa terdapat beberapa solusi dalam mendapatkan simpati dan kepercayaan dari anak didik dengan tanpa harus menggunakan kekerasan yaitu; Keakraban penuh Keterbukaan, komunikasi yang jujur, menghormati kebebasan dan persamaan, memunculkan rasa kasih sayang, saling mempecayaai satu dengan lainnya, tindakan alternatif serta ketekunan dan kesabaran. ${ }^{34}$ Solusi tersebut sebagai langkah awal dalam memperbaiki kualitas pendidikan dengan terus mengubah paradigma pendidikan ke arah yang lebih baik. Dengan mengubah paradigma tersebut secara tidak langsung pola pendidikan yang diterapkan oleh lembaga atau institusi dapat diketahui dan dikontrol oleh semua pihak guna menghindari praktek kekerasan yang sering terjadi dalam pendidikan yang dapat mempengaruhi pembentukan pola pikir peserta didik.

Solusi lain dalam menanggulangi kekerasan dalam pendidikan yaitu dengan menerapkan pola pendidikan yang berorientasi pada terpenuhinya kebutuhan psikis dan spritual. Seringkali praktik Pendidikan hanya melihat kebutuhan fisik saja, dan mengabaikan kebutuhan psikis dan spiritual. Padahal menurut Maslow ada lima hirarki kebutuhan manusia, salah satunya adalah kebutuhan psikis seperti perasaan aman, nyaman dan damai. ${ }^{35}$ Hal semacam ini memang sering kita abaikan dalam Pendidikan, guru lebih mementingkan tercapainya tujuan pembelajaran yang mengarah pada

33 Azyumardi Azra, Paradigma Baru Pendidikan Nasional: Rekonstuksi dan Demokratisasi (Jakarta: publisher: kompas, 2002),234,

${ }^{34}$ Moh. Alifuddin, Reformasi Pendidikan; Strategi Inovatif Peningkatan Mutu Pendidikan (Jakarta: Magna Script Publishing, 2012), 99.

35 Hasan Mustafa, 'Perilaku Manusia Dalam Perspektif Psikologi Sosial', Jurnal Administrasi Bisnis 7, no. 2 (2011). 
kecerdasan kognitif semata tanpa memperhatikan kecerdasan emosional dan spritual, sehingga Pendidikan terasa hampa dan tidak bermakna.

Lebih lanjut, pendidikan juga memiliki solusi tambahan yang ditawarkan dalam mencegah kekerasan saat ini yaitu adanya nilai perdamaian dalam konsep pendidikan modern. Konsep pendidikan yang dikenal dengan pendidikan perdamaian (peace education) menjadi salah satu jembatan tersendiri dalam menyelesaikan problem pendidikan yang ada, khususnya dalam hal kekerasan. Pemahaman tentang nilai-nilai kehidupan yang selalu dimunculkan dalam konsep pendidikan perdamaian tentunya tidak hanya dapat dipahami oleh peserta didik, akan tetapi dapat dipahami oleh pendidik yang mengajarkannya. Secara tidak langsung dengan adanya persamaan perspektif antara pendidik dan peserta didik akan timbul hubungan emosional yang erat dan mengarah pada kerjasama yang positif dalam menuju tujuan pendidikan yang seutuhnya. ${ }^{36}$

Melalui pendidikan perdamaian peserta didik tidak hanya dilatih secara konseptual saja, akan tetapi lebih kepada mengasah keterampilan untuk bersikap bijak dalam mengatasi permasalahan yang dihadapinya dengan cara menghindari konflik, dan kekerasan. ${ }^{37}$ Lebih jauh lagi mereka akan dilatih bagaimana meredam konflik agar tercipta kondisi atau lingkungan yang damai, baik secara intrapersonal dalam dirinya sendiri, maupun secara interpersonal dengan dengan orang lain, pada tingkat nasional ataupun internasional.

Menurut John Dewey ada tiga hal yang menjadi landasan nilai dari pendidikan perdamaian yaitu pertama, nilai kepercayaan moralitas, kedua, nilai-nilai demokrasi dan ketiga, nilai etika religius. ${ }^{38}$ Ketiga nilai ini harus menjadi landasan atau dasar implementasi pendidikan perdamaian. Pendidikan perdamaian harus dapat membangun kepercayaan tentang nilai moralitas, dilaksanakan secara demokratis dan dibingkai dengan etika keagamaan. Jadi bukan pendidikan yang sekuler dan otoriter, yang cenderung mengabaikan aspek-aspek moralitas dan religius serta pemaksaan (seperti indoktrinasi). Untuk mewujudkan mimpi tersebut menurut John Dewey peran sekolah sangat tepat. Karena sekolah dapat berfungsi sebagai dasar perubahan yang dinamis dan membuat pola kehidupan masyarakat di atas perdamaian, serta melalui sekolah

\footnotetext{
${ }^{36}$ Sunaryo Kartadinata, dkk, Pendidikan Kedamaian ( Bandung: Remaja Rosdakarya, 2015), 57.

37 Ibid., 68.

38 Imam Machalli, “Peace Education dan Deradikalisasi Agama”, Jurnal Pendidikan Islam. Volume II, Nomor 1, (Juni 2013): 47.
} 
juga peserta didik dapat menyadari tentang urgensi membangun kehidupan nir kekerasan.

Pendidikan perdamaian, seperti halnya pendidikan pada umumnya, dimana dilakukan proses transfer pengetahuan, juga proses transformasi cara berpikir (mind set), sikap (behaviour) dan perilaku (attitude) melalui seperangkat pengetahuan dan nilai-nilai. ${ }^{39}$ Dalam konteks ini, pengetahuan dan nilai yang diutamakan adalah pengetahuan dan nilai yang berkenaan dengan pengetahuan. Kemudian, tujuan dari pendidikan perdamaian, tentu saja bukan hanya sekedar menyetuh dimensi kognitif atau sebagai ilmu pengetahuan semata, akan tetapi yang paling penting adalah pada aspek praktis. Harapannya adalah peserta didik dapat mengimplementasikan gagasan, pengetahuan, keahlian dan nilai-nilai di dalam kehidupan sehari-hari.

Secara umum dapat digambarkan sebagai berikut hubungan antara pengetahuan, keterampilan dan sikap dalam merumuskan pendidikan perdamaian.

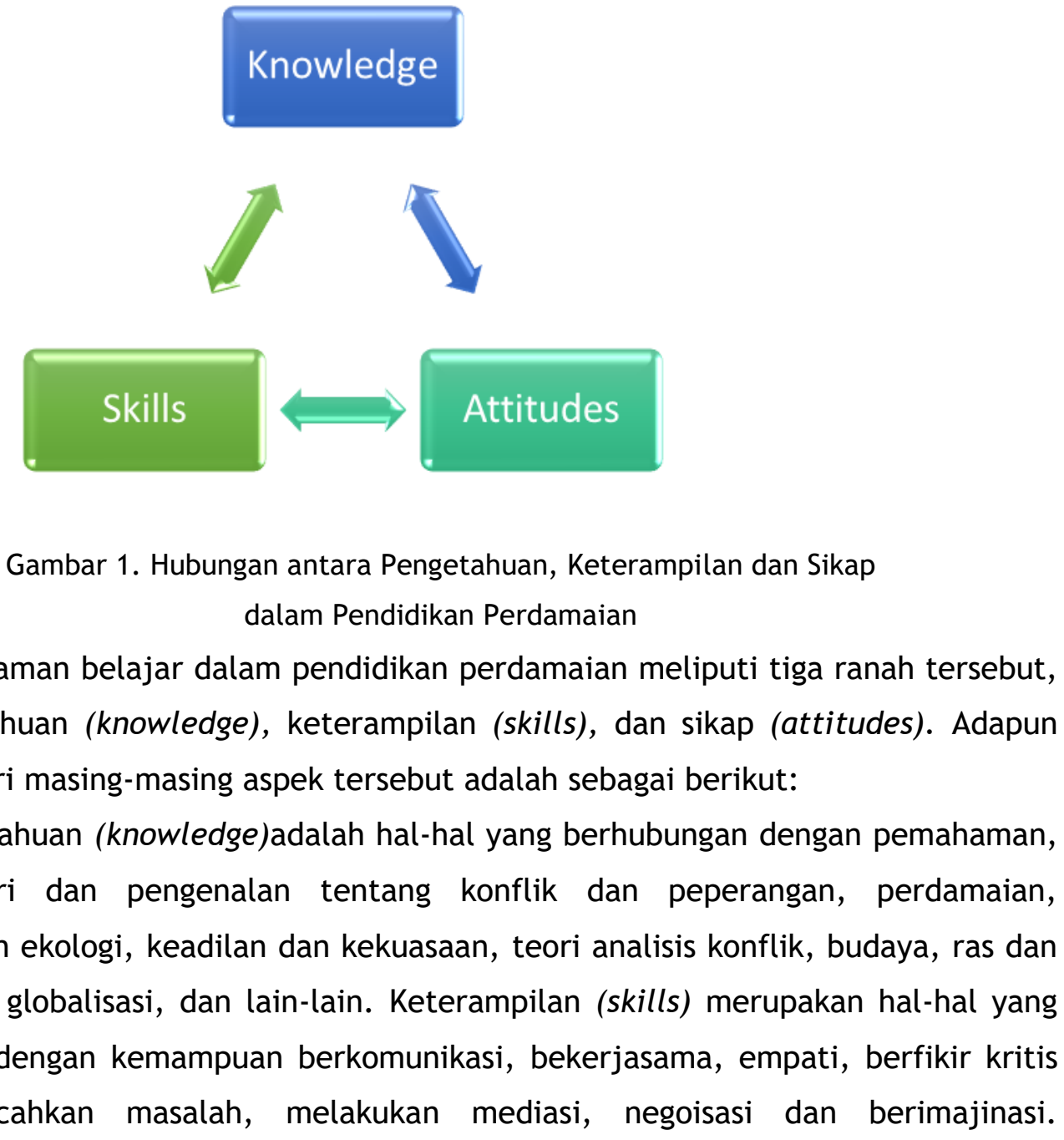

${ }^{39}$ Sunaryo Kartadinata, dkk, Pendidikan Kedamaian ( Bandung: Remaja Rosdakarya, 2015), 110. 
Sedangkan sikap (attitudes) merupakan hal-hal yang berhubungan dengan kemampuan tentang kesadaran ekologis, menghormati orang lain, memiliki sikap toleran, keberpihakan gender, bertanggung jawab dan solidaritas yang tinggi.

Hal ini senada dengan pendapat Gus Dur bahwa melalui pembelajaran pendidikan perdamaian yang holistik-partisipatif akan menciptakan proses pendidikan yang humanis. ${ }^{40}$ Selanjutnya Gus Dur menyebutkan dalam konsep pendidikan Islam, pendidikan perdamaian harus mengedepankan nilai-nilai toleransi, moderat dan religius. ${ }^{41}$ Sebagaimana yang termaktub dalam Q.S. An-Nahl ayat 90.

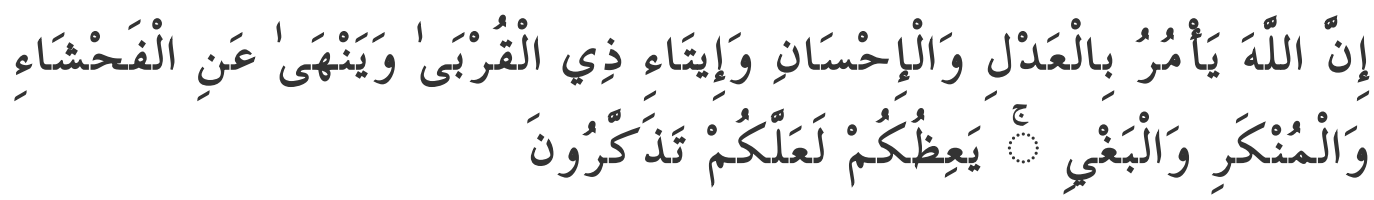

Artinya: Sesungguhnya Allah menyuruh (kamu) Berlaku adil dan berbuat kebajikan, memberi kepada kaum kerabat, dan Allah melarang dari perbuatan keji, kemungkaran dan permusuhan. Dia memberi pengajaran kepadamu agar kamu dapat mengambil pelajaran. (Q.S. An-Nahl: 90).

Dari penjelasan ayat tersebut nampak sekali bahwa Islam sangat menjunjung tinggi nilai-nilai keadilan, dan kebajikan, serta melarang perbuatan keji dan mungkar bahkan kekerasan atau permusuhan. Sehingga penting sekali kiranya menanamkan nilainilai kedamaian dengan mengembangkan benih-benih kasih sayang kepada peserta didik dalam proses pendidikan. Baik pendidikan dalam keluarga, sekolah dan masyarakat. Hal itu tentunya sangat penting sekali guna membangun masyarakat yang damai tanpa adanya kekerasan dan diskriminasi.

Perdamaian dalam agama Islam merupakan nilai yang utama yang harus dijunjung tinggi dan diimplementasikan dalam kehidupan sehari-hari. dalam al-Qur'an maupun as-Sunnah dan sejarah Islam banyak sekali diceritakan semangat membangun perdamaian dan keadilan bagi umat manusia baik dalam bentuk perintah maupun ajnjuran. Meskipun kenyataannya tidak dapat dipungkiri bahwa masih banyak persoalan dalam mewujudkan nilai-nilai perdamaian dalam kehidupan bermasyarakat.

\section{E. Kesimpulan}

Sejarah kekerasan dari masa ke masa terjadi disebabkan adanya faktor intern dan faktor ekstern. Kekerasan dalam dunia pendidikan perlu diperhatikan secara khusus mengingat dampaknya yang sangat besar dalam keberlangsungan proses pendidikan

\footnotetext{
40 Ahmad Nur Cholish, Peace Education dan Pendidikan Perdamaian Gus Dur ( Jakarta: Gramedia, 2015 ), 134.

${ }^{41}$ Halimatus Sa'diyah, "Pendidikan Perdamaian Perspektif Gus Dur : Kajian Filosofis Pemikiran Pendidikan Gus Dur”, Tadris: Jurnal Pendidikan Islam, Vol.14, No.2, (2019): 175-188.
} 
berkaitan dengan fisik dan psikis peserta didik serta berdampak terhadap karakternya. Pendidik sudah seharusnya mencari solusi berkelanjutan baik secara konsep dan aplikasi serta harus direalisasikan dengan maksimal. Tawaran pendidikan perdamian dalam perspektif Gus Dur perlu dipertimbangkan dengan melihat perkembangan dan kebutuhan zaman, sehingga tindak kekerasan yang terjadi dapat diminimalisir atau bahkan dihilangkan dari dunia pendidikan guna mencapai tujuan pendidikan yang seutuhnya.

\section{F. Referensi}

Alifuddin, Moh. Reformasi Pendidikan; Strategi Inovatif Peningkatan Mutu Pendidikan. Jakarta: Magna Script Publishing, 2012.

Anies, R. Baswedan. 'Gawat Darurat Pendidikan di Indonesia', in The Emergency of Indonesian Education]. A Paper Delivered at the Meeting between Ministry and Head of Education Offices Indonesia-Wide in Jakarta, on December, vol. 1, 2014.

Assegaf, Abd. Rahman. Pendidikan Tanpa Kekerasan: Tipologi Kondisi, Kasus dan Konsep. Yogyakarta: Tiara Wacana, 2004.

Azra, Azyumardi. Paradigma Baru Pendidikan Nasional: Rekonstuksi dan Demokratisasi. Jakarta: Kompas, 2002.

Cholish, Ahmad Nur. Peace Education dan Pendidikan Perdamaian Gus Dur. Jakarta: Gramedia, 2015.

Fuad, Syaiful., et. al. "Strategi Guru Pendidikan Agama Islam dalam Menanggulangi Tindakan Bullying Siswa”. EL-BANAT: Jurnal Pemikiran dan Pendidikan Islam, Vol.11 No.1 (2021).

Garver, Newton. "What violence is"? dalam Philosophy a New Generation. New York: A.K. Bierman dan J Gould, 1970.

Gosita, Arif. Masalah Perlindungan Anak. Depok: FHUI, 2004.

Kartadinata, Sunaryo., dkk. Pendidikan Kedamaian. Bandung: Remaja Rosdakarya, 2015.

Kata Data, Anak Indonesia Alama Kekerasan di Sekolah, dalam https: / /databoks.katadata.co.id/datapublish/2017/02/10/84-anak-indonesiaalami-kekerasan-di-sekolah. Diakses pada 22 Januari 2021.

Keliat. Model Praktik Keperawatan Jiwa. Jakarta: EGC, 2012.

Kurniasari, Alit. "Dampak Kekerasan Pada Kepribadian Anak”, Sosio Informa, Vol.5, No.1 (Januari, 2019): 1-10.

Machalli, Imam. "Peace Education dan Deradikalisasi Agama”. Jurnal Pendidikan Islam. Volume II, Nomor 1, (Juni 2013). 
Marno. Manajemen dan Kepemimpinan Pendidikan Islam. Malang: Refika Aditama, 2008.

Martahan, Sohuturon. 'Kronologi Siswa Aniaya Guru Hingga Tewas Di Sampang', nasional, accessed $31 \quad$ December 2019, https://www.cnnindonesia.com/nasional/20180202124909-12273381/kronologi-siswa-aniaya-guru-hingga-tewas-di-sampang.

Mastuhu. Pendidikan Indonesia dari Jaman ke Jaman. Jakarta: Balai Pustaka, 2003.

Media Indonesia, "Kekerasan dalam Pendidikan", dalam https://mediaindonesia.com/read/detail/100955-kekerasan-dalam-pendidikan. Diakses 30 Desember 2020.

Mustafa, Hasan. 'Perilaku Manusia Dalam Perspektif Psikologi Sosial', Jurnal Administrasi Bisnis, Vol. 7, No. 2 (2011).

Nur Cahyono, Arinto. “Kekerasan sebagai fenomena Budaya: Suatu Pelacakan Terhadap Akar Kekerasan di Indonesia”. Mimbar: Vol. XIX, No.3, (Juli -September 2003): 243-260.

Prinst, Darwan. Hukum Anak Indonesia. Bandung: PT. Citra Aditya Bakti, 2003.

Sa'diyah, Halimatus. "Pendidikan Perdamaian Perspektif Gus Dur : Kajian Filosofis Pemikiran Pendidikan Gus Dur”. Tadris: Jurnal Pendidikan Islam, Vol.14, No.2, (2019): 175-188.

Science Direct, "Emotional Discomfort among School Staff and Student Teachers When They Had to "tell" or "Not Tell" about Vague Suspicions of Domestic Violence ScienceDirect', accessed 31 December 2020.

Sjamsuddin. Sejarah Pendidikan Di Indonesia Zaman Kemerdekaan. Jakarta: Direktorat Jenderal Kebudayaan, 1993.

Susanto, Zuhdi. Identitas Bangsa, Sejarah Pendidikan Di Indonesia. Denpasar: Pustaka Larasan, 2010.

Susanto. Identitas Bangsa, Sejarah Pendidikan Di Indonesia.

Tilaar, H.A.R, Kekuasaan Dan Pendidikan Pengantar Pedagogik Transformatif Untuk Indonesia. Magelang: Indonesia Tera, 2012.

UU No. 20 Tahun 2003 tentang Sistem Pendidikan Nasional, disahkan pada 8 Juli 2003. 